\title{
Penetrating head trauma with four nails: an extremely rare case
}

\author{
Dört adet çivi ile çok nadir bir penetran kafa travması olgusu
}

\author{
Lutfü ARICI, ${ }^{1}$ Bekir AKGÜN, ${ }^{1}$ Metin KAPLAN, ${ }^{1}$ İlhan YILMAZ ${ }^{2}$
}

We present a rare case of self-inflicted penetrating head trauma by a 34-year-old male who hammered four nails into his own head; he had been diagnosed with schizophrenia seven years before. On the physical examination, four nails were observed in the hairy scalp that had been driven into the cranium in the right temporal and parietal areas of the head. No cerebrospinal fluid fistulas were present. On the neurological examination, no motor or sensory deficits were present. The Glasgow Coma Scale was 15. On direct skull X-ray and cranial computerized tomography (CT), the nails were seen to be approximately $10 \mathrm{~cm}$ long and extending in various directions. No injury was observed in the main vasculature on CT angiography. Under general anesthesia, two nails in the right temporal area were removed by extraction, and the other two nails in the right parietal area were removed through a mini craniotomy. In areas such as the temporal area where the bone is thin, nails can be removed by extraction. However, in areas like the parietal bone where the bone is thick, removal of the nails using this method may not always be possible.

Key Words: Nail; penetrating head trauma; schizophrenia.
Yedi yıl önce şizofreni tanısı almış, 34 yaşındaki erkek hastanın kendi kafasına 4 adet çivi çakmasıyla gelişen nadir bir penetran kafa travması olgusu sunuldu. Fiziksel incelemede kafasının sağ temporal ve paryetal bölgesinde saçlı deri içerisinde kraniyuma çakılı 4 adet çivi vardı. Beyin omurilik sıvısı fistülü yoktu. Hastanın nörolojik incelemesinde motor ve duyu defisiti yoktu. Glasgow koma skoru 15 idi. Direkt kafa grafisinde ve beyin bilgisayarlı tomografisinde (BT) çivilerin yaklaşık $10 \mathrm{~cm}$ uzunluğunda olduğu ve değişik yönlere uzandığı görüldü. BT anjiyografisinde büyük vasküler yapılarda yaralanma yoktu. Genel anestezi altında sağ temporal bölgede olan 2 çivi direkt çekilerek, sağ paryetal bölgede olan 2 çivi ise mini kraniyotomiler ile çıkarıldı. Temporal bölge gibi kemiğin ince olduğu alanlarda çivi direkt çekilip çıkarılabilir. Ancak paryetal kemik gibi kemiğin kalın olduğu bölgelerde bu yöntemle çivilerin çıkarılması her zaman mümkün olmayabilir.

Anahtar Sözcükler: Çivi; penetran kafa travması; şizofreni
The great majority of penetrating head traumas due to misuse of nails are observed in schizophrenic patients and patients with major depression. The risk of death due to these injuries is $40 \%$. The major causes of death are injuries of the main vasculature and infections. ${ }^{[1-5]}$ Penetrating head traumas caused by nails are usually inflicted upon others. ${ }^{[6]}$ Our case is interesting since the penetrating head trauma with nails was selfinflicted.

\section{CASE REPORT}

A 34-year-old male patient, who was presented after having hammered four nails into his own head, was examined in the emergency room. He had been diagnosed with schizophrenia seven years before. It was ascertained that he had not received regular treatment in the last few years.

On the neurological examination, there was no loss of consciousness or lateralization findings, and his relatives did not report seizures. The Glasgow Coma Scale was 15. Four nails were observed on the skull X-ray (Fig. 1a).

Optimal evaluation could not be performed on the cerebral computerized tomography (CT) due to the presence of artefacts caused by the nails. However, 
according to the observations, no serious parenchymal lesion was detected (Fig. 1b). Three-dimensional cranial CT imaging demonstrated that the nails had penetrated into the cranium (Fig. 1c). No vascular injury was observed on the preoperative cerebral CT angiography (Fig. 1d).

The patient was operated under general anesthesia. The two nails in the right temporal area were pulled out directly after a mini scalp incision. The nails on the right parietal area could not be extracted, so a mini craniotomy was performed around the nails. The defect in the dura mater in the region where the nails were extracted directly was too small for surgical repair; these regions were covered by Spongostan. In the mini craniotomy regions, we performed primary duraplasty before covering with Spongostan. In all of
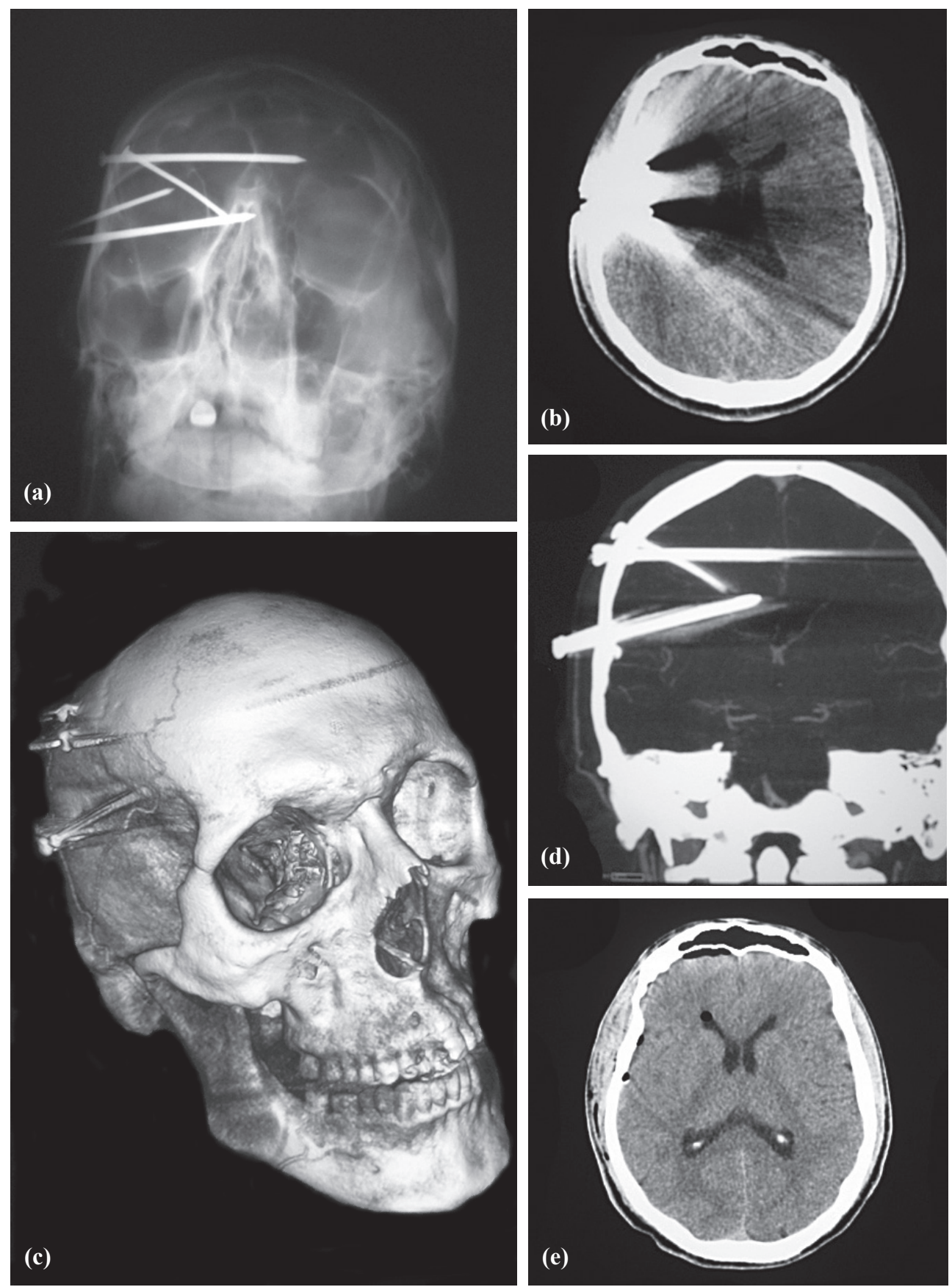

Fig. 1. (a) Four nails penetrating the cranium are observed on direct skull X-ray. (b) Dense artefact caused by the nails can be observed on cerebral CT. (c) Nails penetrating into the cranium can be observed on three-dimensional (3D) cranial CT. (d) No vascular injury is observed on the preoperative cerebral CT angiography. (e) No serious pathological lesions other than millimetric pneumocephaly are observed on the follow-up cerebral CT. 
the surgical areas, skin and subcutaneous tissues were sutured tightly, so no cerebrospinal fistulas were observed. No pathological lesions other than millimetric areas of pneumocephaly were observed on the followup cerebral CTs in the postoperative period (Fig. 1e). We followed the patient postoperatively for five days in the neurosurgery clinic. After this management and in view of the patient's good general condition, no abnormal findings detected on the neurological examination, and the cleanness of the wounds, his psychiatric disease was followed in a psychiatry clinic for continuation of his required treatment. A specially equipped mental health hospital was recommended during the follow-up in light of the risk of injury to himself or his relatives.

Unfortunately, despite all attempts, he did not present for late postoperative follow-ups. Thus, long-term imagings (CT, magnetic resonance [MR] or MR-angiography) were not performed. No complaints were conveyed by the patient or his relatives by telephone.

\section{DISCUSSION}

Nails are an easily accessible material with highly penetrant and powerful drilling properties. ${ }^{[1,4]}$ Penetrating skull and brain injuries are observed rarely, constituting $0.4 \%$ of all head traumas. ${ }^{[7]}$ Injuries with nails constitute $33.3 \%$ of this group. Injuries that occur in psychiatric disorders constitute $66.7 \%$, and are usually inflicted upon another individual by the person with the psychiatric disorder. ${ }^{[6]}$ This condition has been observed frequently especially in schizophrenia and major depressive disorder. ${ }^{[1-5]}$

Intracerebral hematoma is one of the most important causes of mortality in strongly penetrant head traumas such as those caused by nails. These are usually rare and constitute less than $1 \%$ of wide intracranial aneurysm series and can be multiple. ${ }^{[8]}$ Traumatic pseudoaneurysms usually rupture in the third week of the post-traumatic period and are mortal in $50 \% .^{[9,10]}$ Pseudoaneurysms can develop in hours to years after penetrating traumas, with an average time to development of two to three weeks. ${ }^{[9]}$ Pseudoaneurysms due to trauma can be demonstrated in the early preoperative period and between the fourth and seventh postoperative days..$^{[2,3,11]}$ No vascular injury was detected on the preoperative cerebral CT angiography in our patient. Intracranial abscess, ${ }^{[12]}$ meningitis ${ }^{[1-3,5]}$ and seizures $^{[13]}$ are among complications that have been reported in the literature to occur following penetrating head traumas. No such complications developed in the postoperative follow-up of our patient.

There are two known methods in the surgical treatment. These include the application of emergency cra- niotomy under general anesthesia, ${ }^{[14]}$ and direct extraction of the nails from the skull under local anesthesia. ${ }^{[3]}$ In our patient, the nails in the temporal area were extracted under general anesthesia. Mini craniotomy was performed for removal of the nails in the parietal area. Since the parietal bone is thick, extraction of the nails is not as easy as in the temporal area. Powerful manipulations and manipulations in various directions can injure the cerebral parenchyme and augment the existing injury. Mini craniotomy should therefore be chosen in such cases. In multiple penetrant injuries with nails extending in various directions, a single craniotomy to manipulate all of the nails can increase the extent of the parenchymal injury. For this reason, separate mini craniotomies should be performed and the nail should be pulled out together with the bone in accordance with the penetration angle of the nail.

\section{REFERENCES}

1. Musa BS, Simpson BA, Hatfield RH. Recurrent self-inflicted craniocerebral injury: case report and review of the literature. Br J Neurosurg 1997;11:564-9.

2. Rezai AR, Lee M, Kite C, Smyth D, Jafar JJ. Traumatic posterior cerebral artery aneurysm secondary to an intracranial nail: case report. Surg Neurol 1994;42:312-5.

3. Sakuta Y, Arai S. Penetrating brain injury and traumatic aneurysm caused by a nail gun. No Shinkei Geka 1997;25:35762. [Abstract]

4. Shenoy SN, Raja A. Unusual self-inflicted penetrating craniocerebral injury by a nail. Neurol India 2003;51:4113.

5. Viswanathan R, MacArthur DC, Whittle IR. Nail gun injury to the brain: an unusual case of suicide. Scott Med J 1994;39:83.

6. Litvack ZN, Hunt MA, Weinstein JS, West GA. Self-inflicted nail-gun injury with 12 cranial penetrations and associated cerebral trauma. Case report and review of the literature. J Neurosurg 2006;104:828-34.

7. Gennarelli TA, Champion HR, Sacco WJ, Copes WS, Alves WM. Mortality of patients with head injury and extracranial injury treated in trauma centers. J Trauma 1989;29:1193202.

8. Haddad FS, Haddad GF, Taha J. Traumatic intracranial aneurysms caused by missiles: their presentation and management. Neurosurgery 1991;28:1-7.

9. Holmes B, Harbaugh RE. Traumatic intracranial aneurysms: a contemporary review. J Trauma 1993;35:855-60.

10. Voelker JL, Ortiz O. Delayed deterioration after head trauma due to traumatic aneurysm. W V Med J 1997;93:317-9.

11. Larson PS, Reisner A, Morassutti DJ, Abdulhadi B, Harpring JE. Traumatic intracranial aneurysms. Neurosurg Focus 2000;8:4

12. Horner FA, Berry RG, Frantz M: Broken pencil points as a cause of brain abscess. N Engl J Med 1964;271:342-45.

13. Aulino JM, Gyure KA, Morton A, Cole JW. Temporal lobe intraparenchymal retained foreign body from remote orbital trauma. AJNR Am J Neuroradiol 2005;26:1855-7.

14. Rahman NU, Jamjoom A, Jamjoom ZA, Abu el-Asrar A. Orbito-cranial injury caused by penetrating metallic foreign bodies: report of two cases. Int Ophthalmol 1997;21:13-7. 